\title{
JOURNAL.RU
}

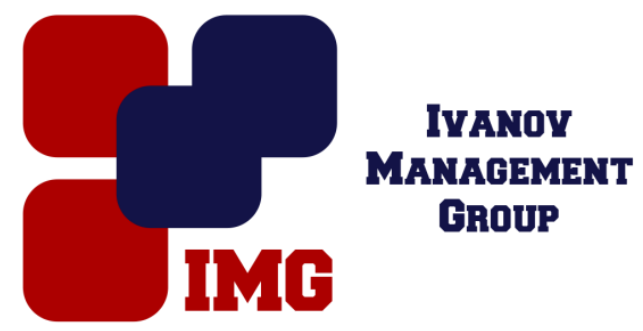

Баиров С.А.

Бурятский государственный университет Улан-Удэ, Россия

doi: 10.18411/lj-31-07-2017-39

idsp 000001:1j-31-07-2017-39

\section{Некоторые вопросы разграничения полномочий в сфере государственной гражданской службы субъектов РФ}

\section{Аннотация}

В настоящей статье раскрываются вопросы разграничения предметов ведения и полномочий субъектов РФ и РФ в сфере установления государственной гражданской службы. Кроме того, в настоящей статье проанализирован характер публично-правовой природы государственной гражданской службы субъектов РФ.

Ключевые слова: государственная гражданская служба субъектов РФ, разграничение полномочий и предметов ведения, региональное законодательство.

На сегодняшний день нельзя сказать, что процесс становления института государственной гражданской службы завершен. Необходимо понимать, что с течением времени общественные отношения так или иначе изменяются, и соответственно вместе с ними нормативно-правовая база, регулирующая эти общественные отношения. Федеральное и региональное законодательство по вопросам государственной гражданской службы постепенно подвергается изменениям и корректировкам

Эффективное развитие системы государственной гражданской службы невозможно в условиях отсутствия четкого разграничения полномочий между РФ и ее субъектами. Конституция РФ недостаточно четко регламентирует вопросы разграничения полномочий. В конституции РФ не содержится 
полноценного положения о том, в чьем ведении находится осуществление организации государственной гражданской службы субъектов РФ. В соответствии со ст. 11 Конституции РФ разграничение полномочий между РФ и ее субъектами устанавливается Конституцией, Федеральными, нормативными договорами о разграничении предметов ведения и полномочий. Эти полномочия, установленные нормативными актами, не подлежат изменению. При этом субъекты РФ обладают всей полнотой власти в части, не установленной законодательством. Конституция РФ не относит вопросы регулирования государственной гражданской службы к совместному ведению РФ и ее субъектов. Основным законом только установлено, что федеральная государственная гражданская служба относится к исключительному ведению РФ. В таком случае логично, что государственная гражданская служба субъектов должна находиться в совместном ведении РФ и ее субъектов.

Нормативно-правовые акты, регулирующие вопросы государственной гражданской службы установлением правовых норм определяют обязательные для исполнения субъектами РФ нормы, относящие государственную гражданскую службу субъектов к совместному ведению РФ и субъектов.

В качестве конституционных основ для отнесения государственной службы субъектов РФ к совместному ведению РФ и субъектов РФ являются пункты «к», «л», «н» ч. 1 ст. 72 Конституции РФ, т. е. совместное регулирование административного, трудового и других отраслей прав, кадры судебных и правоохранительных органов, установление общих принципов организации системы органов государственной власти. Однако насколько это является обоснованным? Что касается норм трудового права, то они применяются при регулировании отношений, связанных с организацией гражданской службы, равно как и нормы иных отраслей права (например, финансового, уголовного). Согласно ст. 73 Федерального закона от 27 июля 2004 г. № $79 \& \Phi 3$ «О государственной гражданской службе в Российской Федерации» нормы трудового права применяются к отношениям, связанным с организацией и прохождением государственной гражданской службы, если иное не установлено законодательством о государственной гражданской службе.

Таким образом, установлено субсидиарное применение норм трудового права. Однако природа норм трудового законодательства и законодательства о государственной гражданской службе различна. Это различие отмечают и приверженцы позиции, рассматривающие отношения, возникающие в процессе прохождения государственной службы. 
Однако природа норм трудового законодательства и законодательства о государственной гражданской службе различна. Это различие отмечают и приверженцы позиции, рассматривающие отношения, возникающие в процессе прохождения государственной службы, как трудовые. Ими указывается на публичный характер отношений по прохождению государственной службы, отмечается особый статус работодателя (публичное образование), фактическое отсутствие условий служебного контракта. В связи с этим отношения в области гражданской службы определяются специалистами в области трудового права «как особые в системе трудовых правоотношений - служебно-трудовые, т. е. имеющие публичный характер».

Таким образом, государственная служба является особым, обособленным комплексом общественных отношений. В трудовом законодательстве не учитывается публично-правовая природа государственной службы. Трудовое законодательство как отрасль частного права не соответствует базовым условиям субсидиарного применения по отношению к госслужащим.

К предметам совместного ведения Российской Федерации и субъектов Российской Федерации относятся также кадры судебных и правоохранительных органов. Представляется, что относить данные вопросы к отношениям, связанным с государственной гражданской службой, неверно. Это положение предоставляет субъектам РФ право участвовать в согласовании назначения на определенные должности в данных органах. Некоторыми учеными высказывалось мнение о том, что в соответствии с п. «н» ст. 72 Конституции РФ государственная служба субъектов Федерации находится в совместном ведении РФ и субъектов Федерации. Однако на практике такая позиция не получила поддержки. Принятый в соответствии с п. «н» ст. 72 Конституции РФ Федеральный закон от 6 октября 1999 г. № 184\&Ф3 «Об общих принципах организации законодательных (представительных) и исполнительных органов государственной власти субъектов Российской Федерации» включил в предмет регулирования систему законодательных (представительных) и исполнительных органов государственной власти субъектов РФ, образование, формирование, деятельность указанных органов, их полномочия и ответственность, порядок взаимодействия между собой и с федеральными органами государственной власти. То есть государственная служба субъектов РФ не попала в предмет регулирования данного закона. 
Таким образом, мы считаем, что ни один из предметов совместного ведения, указанных в ст. 72 Конституции РФ, не позволяет отнести государственную службу к совместному ведению РФ и субъектов РФ.

Российская Федерация является федеративным государством, соответственно, государственная власть осуществляется как на федеральном уровне, так и в субъектах РФ через органы государственной власти (ст. 11 Конституции РФ). Государственная гражданская служба субъекта РФ, по сути, является способом реализации государственной власти субъекта РФ, в связи с чем она должна рассматриваться как самостоятельный институт на уровне субъекта РФ. Поскольку государственная служба не отнесена к исключительному ведению РФ, постольку согласно Конституции России субъекты РФ имеют право осуществлять собственное правовое регулирование в рамках федерального законодательства.

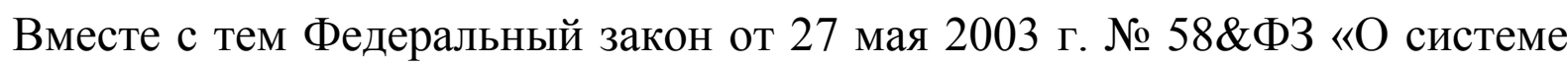
государственной службы Российской Федерации» закрепляет следующее разграничение предметов ведения и полномочий. Согласно п. 4 ст. 2 данного закона правовое регулирование государственной гражданской службы относится к совместному ведению РФ и субъектов РФ, а к ведению субъекта РФ отнесена организация гражданской службы субъекта РФ. По сути, в этом законе произошло перераспределение установленных Конституцией России предметов ведения, и подобное перераспределение не соответствует Конституции РФ.

Таким образом, Федеральный закон «О системе государственной службы Российской Федерации», по сути, установил новые предметы совместного ведения и полномочий РФ и субъектов Федерации, т. е. фактически изменил положения Конституции РФ. Кроме того, возникает вопрос: возможна ли организация гражданской службы без осуществления еe правового регулирования? Ответ очевиден — нет. Организация гражданской службы предполагает установление общеобязательных правил поведения для гражданских служащих и лиц, претендующих на замещение должности государственной гражданской службы, что возможно только путем принятия нормативных правовых актов. Правовое регулирование как таковое не может быть отнесено к ведению РФ или субъекта РФ. Как отмечал В. М. Манохин, в качестве обязательного элемента предмет ведения включает в себя правовое регулирование. Действительно, государственная власть, реализуемая через органы государственной власти, осуществляется по большей части посредством принятия правовых актов. 
Можно разграничить общественные отношения, отнеся их к ведению РФ, субъектов РФ либо к совместному ведению. В случае если вопрос (предмет) признается исключительным ведением РФ, то соответственно субъект РФ лишается каких-либо полномочий по данному предмету, в том числе права осуществлять и правовое регулирование в такой области. Если же вопрос является предметом совместного ведения РФ и субъекта РФ, то на основании ч. 2 ст. 76 Конституции РФ имеет право принимать в соответствии с федеральными законами собственные нормативные правовые акты. Следует отметить, что Конституция РФ имеет прямое действие и обладает высшей юридической силой, следовательно, федеральные законы не могут противоречить нормам Конституции.

Полагаем, что в целях придания устойчивости правоприменительной практике статьи Федерального закона «О государственной гражданской службе Российской Федерации», имеющие такие формулировкиследует изменить, указав либо обязательную для исполнения государственными органами субъектов РФ норму, либо предоставив возможность самостоятельно урегулировать тот или иной аспект общественных отношений в области гражданской службы.

1. Федеральный закон от 27.07.2004 N 79-Ф3 (ред. от 01.07.2017) "О государственной гражданской службе Российской Федерации"// [Электронный ресурс]. Доступ из справ. правовой системы «Консультант Плюс»

2. Гусев А. В. Российская государственнаягражданская служба: проблемы правовогорегулирования. Екатеринбург, 2005. - 132 с.

3. Государственная служба / Под ред. А. В. Оболонского. М., 2000. - 131 с.

4. Манохин В. М. Правотворческая деятельность в субъектах РФ: вопросы методики. Саратов, 2000. - С. 18. 